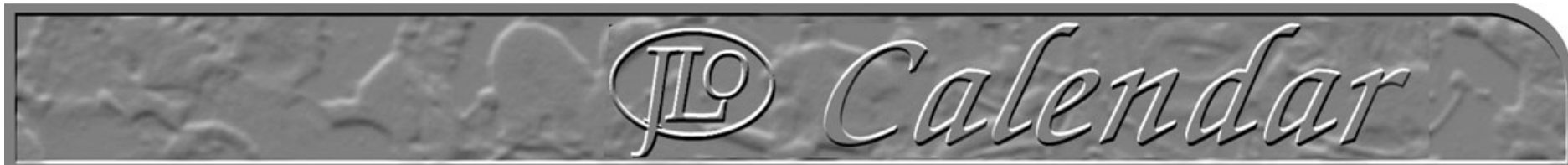

\title{
EVENTS, COURSES AND CONFERENCES
}

\section{9}

\section{July}

13th British Academic Conference in Otolaryngology and ENT Expo July $8-10,2009$

Liverpool, UK

Contact: Nechama Lewis

Tel: $+44(0) 2074048373$

E-mail:nlewis@entuk.org

Website:

\section{August}

10th Asia Pacific Congress on

Deafness \& 10th Hearing

International Annual Meeting \&

2nd ASEAN Academy of Neuro-

Oto-Audiology

August 4-7, 2009

Bangkok, Thailand

Website: www.apcd2009.or

World Congress on Thyroid Cancer August 6-10, 2009

Toronto, Canada

Contact: Congress Secretariat

Tel: + 4169782719

E-mail: help-ENT0909@ cmetoronto.ca

Website: www.thyroid2009 ca

8th Temporal Bone Dissection \&

Microsurgery Ear Workshop

August 15-16, 2009

Muzaffarnagar, India

Contact: Dr M.K. Taneja

Tel: + 91131243773

E-mail: ijo_editor@rediffmail.con

Website: www.otoin.org

\section{September}

27th Politzer Society Meeting (Otology)

September 3-5, 2009

London, UK

Contact: Lauren Sterling

Tel: + 44 (0) 1517067614

E-mail: politzer@sterlingevents.co.uk

Fifth European Course on

Laryngology and Phonosurgery

September 17-19, 2009
Giessen, Germany

Contact: Dr Christoph Arens

E-mail: christoph.arens@hno.med.unigiessen.de

Website: www.uniklinikum-giessen.de

12th Merseyside Ear Course 2009 September 27-29, 2009 Liverpool, UK

Contact: Shonagh Nugent

Tel: + 44 (0) 1515295262

E-mail: Shonagh.nugent@aintree.nhs.co.uk

World Congress on Thyroid

Cancer

Septermber 27-31, 2009

Toronto, Canada

Tel: +1 4169782719

E-mail: help-ENT2009@cmetoronto.ca

Website: www.thyroid2009.ca

\section{October}

Global Postlaryngectomy Course

October 1-2, 2009

Rome, Italy

E-mail: info@gpracademy.com

Website: www.gpracademy.com

113th American Academy of ORL,

Head \& Neck Surgery Annual

Meeting \& OTO EXPO

October 4-7, 2009

San Diego, USA

Contact: Marketing Co-ordinato

E-mail: aaomeet@entnet.or

Website: www.entnet.org

\section{November}

ENT Congress 2009

Novermber 1-4, 2009

Cape Town, South Africa

Website: entsociety co.za

7th Annual Conference of Cochlear Implant Group of India (CIGICON)

November 6-8, 2009

Hyderabad, India

Contact: Dr E.C. Vinaya Kumar

E-mail: cigicon2009@gmail.com

Website: www.cigicon.org

47th Annual Art of Rhinoplasty

Course

Novermber 7-9, 2009

San Francisco, USA

Contact: Prof Lesley Bernstei
Tel: + 19169230820

E-mail: rhinoplastycourse@sbcglobal.net

9th Otological Microsurgery

Course and Oto-endoscopy

November 21-23, 2009

Coimbra, Portugal

Contact: Ms Isabel Rico

Tel: + 351239400450

E-mail: otorrino@huc.min-saude.pt

Website: www.sporl.pt

\section{December}

7th Asia Pacific Symposium on Cochlear Implants and Related

Sciences

December 1-4, 2009

Singapore

Contact; APSCI 2009 Symposium

Manager

Tel: + 6563306730

E-mail: apsci2009@pwevent.com

Website: apsci2009.com.sg

Temporal Bone Course

December 3-4, 2009

Dundee, $U K$

Contact; Mary Burke

Tel: + 44 (0) 1382645857

E-mail: m.t.burke@dundee.ac.uk

Website: www.dundee.ac.uk/surgicalskills

\section{0}

\section{February}

Indian Society of Otology

February 5-7, 2010

Coimbatore, India

Contact: Dr N.J. Rajan

Tel: +09443095756

Website: indiansocietyofotology.com

\section{May}

Combined Universities Course in Advanced Surgical Otology

May 3-6, 2010

Edinburgh, UK

Contact: Julie Murray

Tel: + 44 (0) 1394461131

E-mail: info@scm-ltd.con

\section{June}

4th World Congress of

International Federation of Head

and Neck Oncologic Societies

Seoul, Korea

June $15-19,2010$

Tel: +82220822310

E-mail: ifhnos2010@meci.co.kr

Website: www ifhnos2010.org

\section{September}

The 4th World Voice Congress Seoul, Korea

September 6-9, 2010

Contact: Secretariat

Tel: + 8225666067

E-mail: seoul@voice2010.org

Website: www.voice2010.org

114th American Academy of ORL,

Head \& Neck Surgery Annual

Meeting \& OTO EXPO

Boston, USA

September 26-29, 2010

Contact: Marketing Co-ordinator

E-mail: aaomeet@entnet.org

Website: www.entnet.ors

\section{October}

\section{5th EUHA Congress}

October 13-15, 2010

Hanover, Germany

Tel: + 49 (0) 61 31/28 30-0

E-mail: info@euha.org

Website: euha.org

\section{2}

\section{June}

24th Congress of the European Rhinologic Society

June 17-21, 2012

Toulouse, France

Tel: + 33 (0) 534452645

E-mail: regist-ers@europa-organisation.com 


\section{CAMBRIDGE JULNALS}

\section{Knowledge is no longer shelved}

The Cambridge Journals Digital Archive contains more than 160 journals, more than 3 million pages and more than 8 million linked references. Knowledge is now more visible and more searchable than ever.

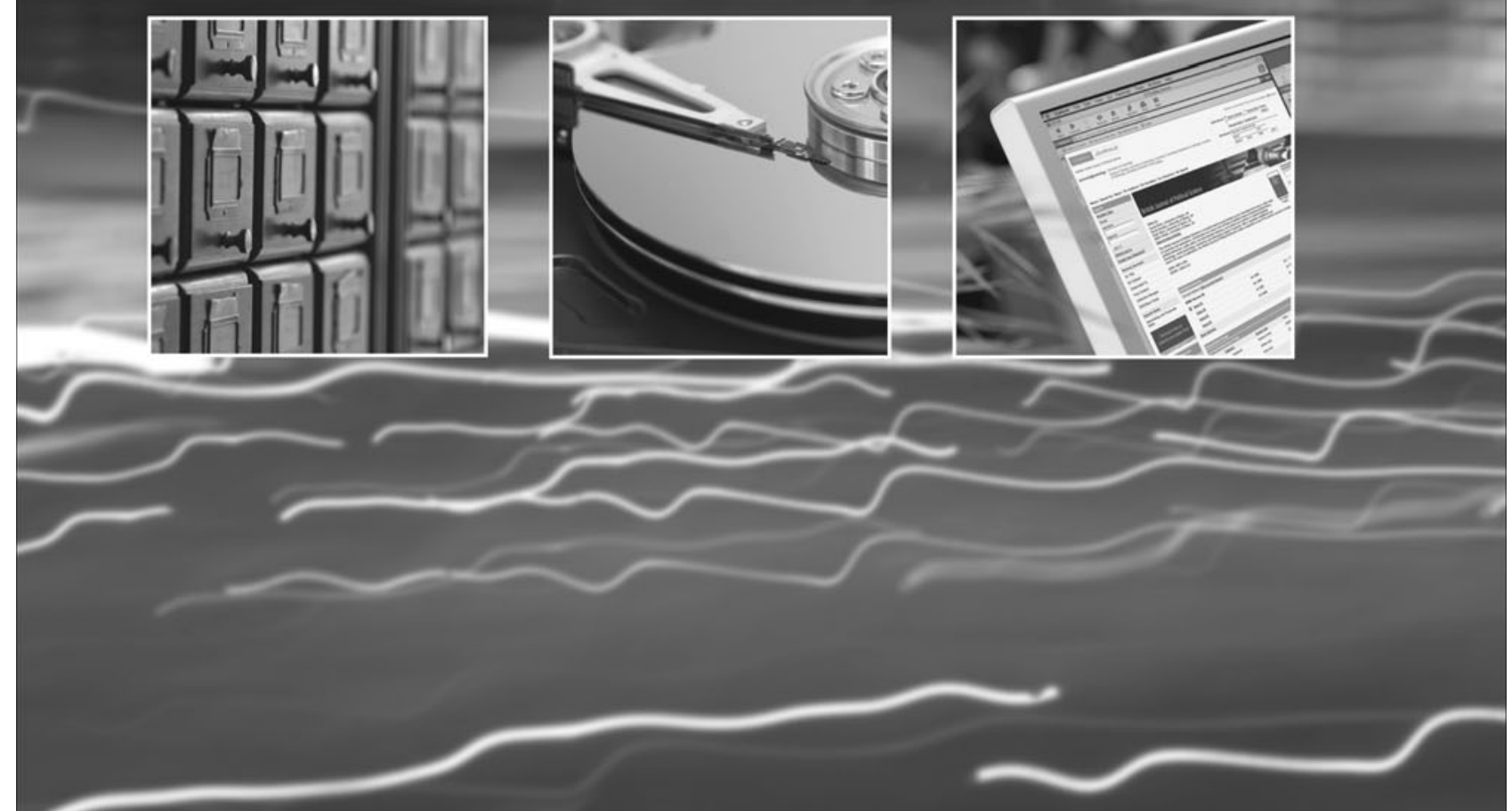

journals.cambridge.org/archives 


\section{The Journal of Laryngology \& Otology}

\section{Vol 123}

\section{Review Articles}

Review of the use of throat packs in nasal surgery: $V$ Jaiswal, GC Bedford

Computed tomography and/or magnetic resonance imaging for pre-operative planning for inverted nasal papilloma: review of evidence: PD Karkos, LC Khoo, SC Leong, H Lewis-Jones, AC Swift

\section{Main Articles}

Hypobaric pressure exposure effects on cochlear frequency selectivity in fluctuating, low-frequency hearing loss: KJ Brännström, J Grenner

Effect of phosphodiesterase-5 inhibitor on hearing: S Okuyucu, OE Guven, E Akoglu, E Uçar, S Dagli

Effect of cochlear implant electrode insertion on middle-ear function as measured by intra-operative laser Doppler vibrometry: N Donnelly, A Bibas, D Jiang, D-E Bamiou, C Santulli, G Jeronimidis, A Fitzgerald O'Connor

Hearing results of 1145 stapedotomies evaluated with Amsterdam hearing evaluation plots: VE Kisilevsky, SN Dutt, NA Bailie, JJ Halik

Comparative evaluation of conventional versus endoscopic septoplasty for limited septal deviation and spur: $R$ Bothra, NN Mathur

Mapping surgical coordinates of the sphenopalatine foramen: surgical navigation study: L Hadoura, C Douglas, GW McGarry, D Young

Use of a screening tool for detection of sleep-disordered breathing: AL Clark, S Crabbe, A Aziz, P Reddy, M Greenstone

Sutter ${ }^{\circledR}$ bipolar radiofrequency volumetric tissue reduction of palate for snoring and mild obstructive sleep apnoea: is one treatment adequate?: KP Pang, JK Siow

Reliability of perceptions of voice quality: evidence from a problem asthma clinic population: C Sellars, AE Stanton, A McConnachie, CP Dunnet, LM Chapman, CE Bucknall, K MacKenzie

Cervical lymphadenopathy: scrofula revisited: $R$ Khan, $S H$ Harris, AK Verma, A Syed

Thyroid tubercle of Zuckerkandl: anatomical and surgical experience from 79 thyroidectomies: C Page, $P$ Cuvelier, A Biet, $P$ Boute, $M$ Laude, V Strunski

Extra-long Montgomery T tube in major airway stenosis: $Y-H$ Liu, $Y-C W u, M-J ~ H s i e h, Y-K$ Chao, C-J Wang, P-J Ko, H-P Liu

Sensitivity and specificity of computed tomography for detection of extranodal spread from metastatic head and neck squamous cell carcinoma: MA Souter, RS Allison, JH Clarkson, IA Cowan, MH Coates, JE Wells

\section{Short Communications}

Trans-nasal injection of botulinum toxin: A Hussain, G Thiel, M Shakeel

Thyroid surgery: the sub-mental drain: $V$ Dhar, $R$ Townsley, M Black, O Laccourreye

Suturing of Little's area of the nasal septum for epistaxis: Z ZhengHua, F Gang, Z BingWei, C JiaWen

\section{Clinical Records}

Primary carcinoid tumour of nasal septum: T Galm, $N$ Turner

Maxillary haemangioma successfully resected by endoscopic approach: T Kanazawa, $R$ Inoue, $Y$ Ohta, $Y$ Watanabe, $Y$ lino

New presentation of familial medullary thyroid carcinoma in 87-year-old patient with high-risk RET proto-oncogene codon 620 mutation: MKJ Jaggard, C MacRae, S Ifeacho, S Robinson, NS Tolley

Rare post-tonsillectomy complication in human immunodeficiency virus positive patient: ulcero-necrotic lesion of tonsillar fossa: PK Singh, A Masood, OP Chawla

Spontaneous intracranial hypotension presenting to the ENT surgeon: case report: $S$ Street, $P$ Fagan, J Roche

Extracorporeal oxygenation support for curative surgery in a patient with papillary thyroid carcinoma invading the trachea: $\mathrm{H}-\mathrm{K}$ Jeon, $\mathrm{YK}$ So, J-H Yang, $\mathrm{H}-\mathrm{S}$ Jeong

Bilateral profound sudden sensorineural hearing loss presenting a diagnostic conundrum in a child with sickle cell anaemia: AD Mace, MS Ferguson, M Offer, K Ghufoor, MJ Wareing

Allergic fungal sinusitis with extensive bone erosion of the clivus presenting with diplopia: SD Reitzen, RA Lebowitz, JB Jacobs 